\title{
漱石の『草枕』に見る絵画的言語空間における建築的空間構図 ARCHITECTURAL SPACE COMPOSITION COMPARED WITH THE PICTURESQUE SPACE DEPICTED IN LANGUAGE AS DELINEATED IN 'KUSAMAKURA' WRITTEN BY SOSEKI
}

\author{
徐 貴 淑* \\ KueeSook SUH
}

\begin{abstract}
The purpose of this thesis is to study KUSAMAKURA written by Soseki and thus find out the meaning of descriptive space as described by the author, and also to find out what architectural composition is connoted in the text. Through the text KUSAMAKURA, Soseki described his own inner consciousness using linguistic description and then developed this into spatial relationship. Picturesque space depicted in language was divided into four kinds of description. Also, the arrangement of materials for spatial composition was classified as three styles of layer composition. It was noted that the whole descriptive space depicted in language started as plane surface and ended in three dimensions. This method of composition was used in the definition of description to outline the descriptive space. Therefore, it could be defined that KUSAMAKURA composed plastic space from literary picture and architectural concept or thought was latent in it.
\end{abstract}

Keywords: KUSAMAKURA , Picturesque space depicted in language, outline, layer composition 草珫、絵画的言語空間、輪郭、層状構図

1. 序

日本における近代文学者として広く知られる、夏目濑石に対する もう一つの濑石の存在虫、いわば絵をかき、絵で考えるともいえる ような彼の絵画に対する芸術家としての噜された願である。被の絵 画活動はおそらく文学活動のながもその影響を与えたものとも考 えられる。その中でも初期作品である「草枕】1)作中の主人 公が尃門の画家として登場し作品のなかで絵をかき、絵に対する自 らの絵画観を論ずるなど、他の作品では見られない絵画的小説とい っても差し支えない作品である。『草枕」には、絵画的モチ一フさ らに絵画にかかわる話、また一つの絵を思わせる文体が数多く描写 されている。国文学側の解积によると、絵画的小説である『草枕」 を通して濑石恃芸術思想を語りか忛ようと試みたと説明している2 )。本稿では、彼の芸術思想を探るものではなく、「草枕」に書か

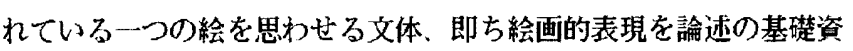
料として取り上计る。ここで絵画的表現とは、実際の絵画を示すも のではなく、ことはで語られる絵画という意味であり、これを本稿 では絵画的言語表現ということにしたい。ことば自体には何の意味 もなく、かつ何かを直接に表現できるとは思えない。しかし、この ようなことはによって絵のような街の風景をつくりあげることはで きる。ことは自体が直接何かを語らなくても、それによって構成さ
れる街であれは何かを語り出すかもしれない。建築もまたことはで できていると見なすことができよう。柱、壁とか階段とかの「こと ば」による表現がそうである。これらはただのモんにすぎないし かしこれらのことばは、並へらられたり他のものと接続されて、初め て何かを語りうる建築空間を生み出すのである。ことはによる小説 もこれに似ったようなものと思われる。ことばでつくりだされる言 語空間、特に『草珫』のなかで作り出された絵画的言語空間が何か を語り出すことに重点を置くのである。

一般的に絵画の表現とは、色と線と形と平面だけで素材になる対 象物を描くことである。ここで一つ重要なことは、描く対象物を見 るという視覚的な図式が横たわっているということである。視覚を 通して見られる詈色恃、時間的に空間的に切り取られた一つの風固 の形象を描いた絵画である。そこには幅，高さ、奥行という空間又 は立体の对象物を観察者の視覚を固定して、平面として表現する平 面的な絵画空間を形成する。今度は、これらを建築の図式として描 く場合、对象物は秩序をなし常に一点に集中していくという遠近法 的パースペクティウとして表現される。ここでの風累は奥行きがあ る空間が形成される。言い換えれは、同じ景色は限られた空間内で 絵画と建筑の図式によって「平面」と「立体」の表現として捉えら れる。しかし、ここで描がる表現が「平面」であり「立体」であ 


\begin{tabular}{|c|c|c|c|c|c|c|c|c|c|c|c|c|c|c|c|c|c|c|c|c|c|c|}
\hline 構成 & \multicolumn{4}{|c|}{ 春の 山 路 } & \multicolumn{3}{|c|}{ 㑐 路 } & \multicolumn{10}{|c|}{ 那古井 の温泉 場 I } & 垡結休 & \multicolumn{4}{|c|}{ 那 古井 の. 盕 } \\
\hline テーマ & $\frac{t}{z}$ & 術 & の 意 & & 住みに & $\langle\omega 世$ & D蜼机 & & 腧 化 & の 温 & 泉 場 & & & 因 果 & の & 辌 き & & 自然の力 & 超自然の影 & 不透 & 明 & 基 \\
\hline 章 & & & - & & & $=$ & & & & $\equiv$ & & & & & 四 & & & $\pi$ & 六 & & $t$ & \\
\hline 番号 & 1 & 2 & 3 & 4 & 5 & 6 & 7 & 8 & 9 & 10 & 11 & 12 & 13 & 14 & 15 & 16 & 17 & 18 & 19 & 20 & 21 & 22 \\
\hline $\begin{array}{l}\text { 絵画的 } \\
\text { 言語 } \\
\text { 空間 }\end{array}$ & $\begin{array}{l}\text { 山 } \\
\text { 路 }\end{array}$ & $\begin{array}{l}\text { 山 } \\
\text { 中 }\end{array}$ & 路 & $\begin{array}{l}\text { 山の } \\
\text { と間 } \\
\text { 山 }\end{array}$ & $\begin{array}{l}\text { 茶 } \\
\text { 屋 }\end{array}$ & $\begin{array}{l}\text { 荼 } \\
\text { 屋 }\end{array}$ & $\begin{array}{l}\text { 茶の } \\
\text { 屋前 }\end{array}$ & $\begin{array}{l}\text { 温の } \\
\text { 泉宿 } \\
\text { 䭪 }\end{array}$ & $\begin{array}{l}\text { 過の } \\
\text { 去宿 }\end{array}$ & 庭 & 座敖 & $\begin{array}{l}\text { 璐部 } \\
\text { 箖㞗 } \\
\text { の }\end{array}$ & 庭 & $\begin{array}{l}\text { 那温 } \\
\text { 古と泉 } \\
\text { 井埸 }\end{array}$ & 庭 & $\begin{array}{l}\text { 葌 } \\
\text { 例 }\end{array}$ & 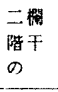 & $\begin{array}{l}\text { 那の } \\
\text { 古捠 } \\
\text { 井 }\end{array}$ & $\begin{array}{l}\text { 蝠の } \\
\text { 空 } \\
\text { 尺間 }\end{array}$ & $\begin{array}{l}\text { 風 } \\
\text { 呂 } \\
\text { 埸 }\end{array}$ & $\begin{array}{l}\text { 㳑 庭 } \\
\text { 去 } \\
\text { の }\end{array}$ & $\begin{array}{l}\text { 阅 } \\
\text { 品 } \\
\text { 埸 } \\
\end{array}$ \\
\hline $\begin{array}{l}\text { 原詞 } \\
\text { 文書 } \\
\text { 上の } \\
\text { り始 } \\
\text { 抽. } \\
\text { 出終 } \\
\text { た } \\
\text { た }\end{array}$ & $\begin{array}{l}\text { 立見 } \\
\text { ちる } \\
\text { 上と } \\
\text { が } \\
\text { る登 } \\
\text { 時れ } \\
\text { にば } \\
\text { 向あ } \\
\text { ふす } \\
\text { を } \\
\text { 見 } \\
\text { る出 } \\
\text { とる } \\
\text { の } \\
\text { 路だ } \\
\text { から } \\
\text { らう } \\
\text { 左。 } \\
\text { の } \\
\text { 方 } \\
\vdots\end{array}$ & 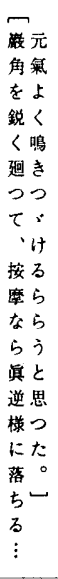 & 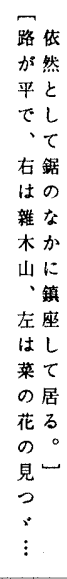 & 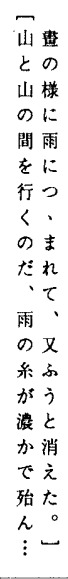 & 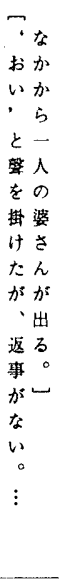 & 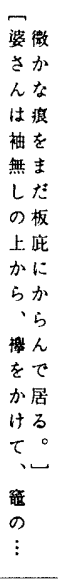 & 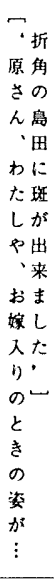 & 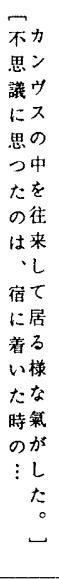 & 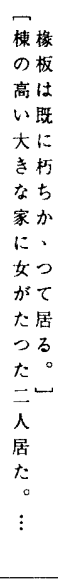 & 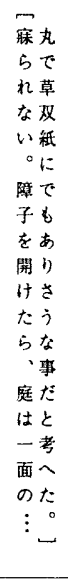 & 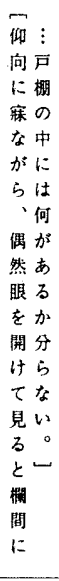 & 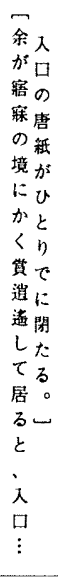 & 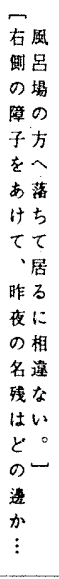 & 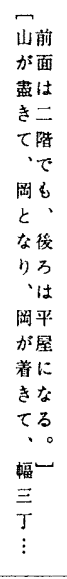 & 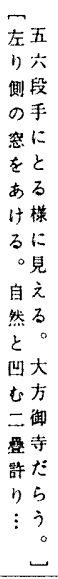 & 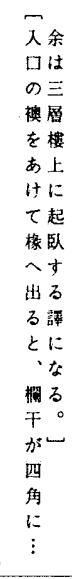 & 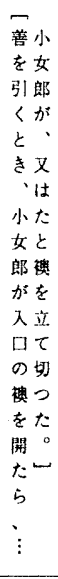 & 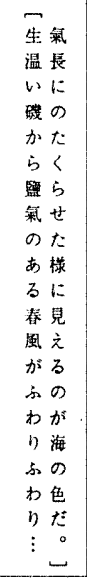 & 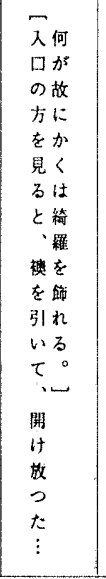 & 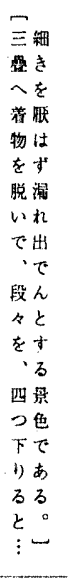 & 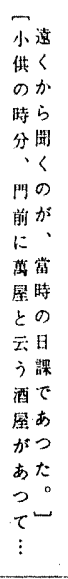 & 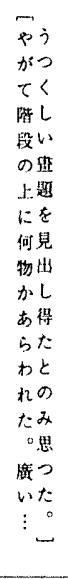 \\
\hline
\end{tabular}

りという形態上の問題ではなく、桧画と建築は同し造形空間として の芸術の表現法による共通点があるということである。絵画の表現 が建築の表現を前提しており、亲たその反対のような結果の交換が 起り得ることを㔔むものである。いわは，桧画の表現と建築のそれ がどこかで類似な点があり相通する点が有り得るといえよう。それ は近代のアヴァ・キャルドとキュービズムが絵画に拊る表象性を 突き抜けるという絵画の再現を構想しはじめることから出発して、 それを一つの貄築モデルの制作へと関係をもって行ったことから、 絵画と建築の関倸を認めることができよう。そうすれは、ことばで 表現される絵画からも同様に建築との類以点が見られるのか。ここ に、本稿では『草枕』からことばで語られる絵画的文体を通して建 筑的な図式を探る。濑石が文学のなかでことばを用いて絵画的空間 を構成するのに、そこには一つの建築的な構図を伴っているという 表明を図ることである。また、そこにはどのような建築的構图が絵 画的言語空間に内在しているかを考察することである。この椂な 研究は、言語活動に内包する建築的空間の性質の追求に意義あるも のと考えられる。それに建築㑡からは、ことばを借りて表現する絵 画的空間を通してことばで表現され得る建築的空間を見い出すとい う広義としての一つの建築表現の提案を試みるものである。この意 味で濑石の文学のなかで『草枕」を用いた理由と、「草枕」の絵画 的言語表現から建築的空間構図を考察する前提が説明できよう。

本稿では次の構成をもって論述される。主に『草枕」から絵画的 言語表現を抽出することで、その絵画的言語空間とその分類を考察 し、次は桧画的言語空間の素材の配置構成から建築的空間桡成の図 式の可能性を試みる。

\section{2.【草枕」の絵画的言語空間}

「草枕」のなかで濑石は桧画的言語空間をどのように表わしてい るかを見ることにする。濑石の分身と見られる主人公である画工の 旅㐫、非人情な世界を求め理想的な美を追求するものである。非人
情とは、「世間的な人情」を離れた「出世間的」3)なものを意味し ており、「第三者の地位」4）に立って物を眺めることであったここ れらのものはすべて自然そのものの中に在って自然らしさ、すなわ ち本然的なかたちをとることであり、それこそ理想的な美であり形 であったのである。「第三者の地位」に立方、もの或いは人を「只 まのあたりに見る」らことに徹し、その向こうに立ち上がるものを つかみとろうとしているのである。見るむのに做しさえすれば、「 無色の畫家」6)として「畫工になり切る」7〕ことができる。「畫な んぞ描いたつて、描かなくつたつて、詰る所は同じ事」8)なのであ

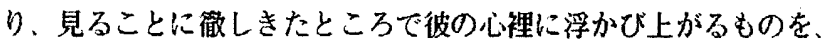
心像として一枚の絵画に仕立て上げればいいのである。これこそ画 工の思考が具体化されて行くものであり、それが絵画として表現さ れたその時には、二十世紀の現実社会のなかで生き㥢む画工にとっ て、初めて「畫家といふ使命」9）を社会に対して果たすことが可能 となってくるのである。このような一枚の絵画の構図を求めて考え を進めて行くことは、明らか忙絵画の空間に批るコンボジション に知覚とその内容が結ばれるという構造の探笢が求められていると 思わ机る。

「草枕」の全編十三章加四十四䈯所の絵画的言語空間を描写し た表現句の抜き出しを（表一1）10ににまとめた。表にお计る上段は 「草珫」の内容による構成とその場所を示し、次の段汢各章のテ一 マをまとめて示した。各々の絵画的言語空間の表現何は文章の長さ の関保上、その始めと終りに当たる表現句をあげた。抽出した表現 句から桧画的言語空間を整理して見ると、一章における「春の山路 」の場所から始まり、二章の「衤路」、三章と四章における「那古 井の温泉場 I」、五章の「坺結床」、六・七・八・九章に执们「「 那古井の温泉場 II」、十章の「鏡が池」、十一章の「観海寺」、十 二章の「山の出鼻」であり、これらの場所怙自然又洁自然の中のあ る場所を指しており、絵画的言語空間梳そのなかで展開さ扎ている 物語はそのなか人と展開されている。そして最後の十三章にお的 


\begin{tabular}{|c|c|c|c|c|c|c|c|c|c|c|c|c|c|c|c|c|c|c|c|c|c|c|c|}
\hline \multicolumn{3}{|c|}{ 泉 場 II } & \multicolumn{3}{|c|}{ 鏡 が 池 } & \multicolumn{6}{|c|}{ 観＼cjkstart海＼cjkstart寺 } & \multicolumn{6}{|c|}{ 山 の 出 鼻 } & \multicolumn{6}{|c|}{ 川 · 默 } \\
\hline \multicolumn{2}{|c|}{ 風雅なお葉席 } & \multirow{3}{*}{$\begin{array}{c}\text { 非人情の仲 } \\
\text { 九 } \\
\end{array}$} & 䁇 & の 輠 & 想 & \multirow{2}{*}{\multicolumn{6}{|c|}{$\frac{+}{+}$}} & 芸 術 & 術 家 & たる & 態 度 & ᄉ & 頽 & \multirow{2}{*}{\multicolumn{6}{|c|}{ 現 実 世 }} \\
\hline 八 & & & & + & & & & & & & & \multicolumn{6}{|c|}{$+=$} & & & & & & \\
\hline 23 & 24 & & 25 & 26 & 27 & 28 & 29 & 30 & 31 & & 32 & 33 & 34 & 35 & 36 & 37 & 38 & 39 & 40 & 41 & 42 & 43 & 44 \\
\hline $\begin{array}{l}\text { 老部 } \\
\text { 人屋 } \\
\text { の }\end{array}$ & 成 & $\begin{array}{l}\text { 無 } \\
\cdots \\
\text { ? }\end{array}$ & $\begin{array}{l}\text { 鏡 } \\
\text { 占 } \\
\text { 池 }\end{array}$ & $\begin{array}{l}\text { 池 } \\
\text { の } \\
\text { 水 }\end{array}$ & $\begin{array}{l}\text { 鏡 } \\
\text { 品 } \\
\text { 池 }\end{array}$ & $\begin{array}{l}\text { 観の } \\
\text { 海石 } \\
\text { 寺段 }\end{array}$ & 山 & $\begin{array}{l}\text { 庫 } \\
\text { 妻 }\end{array}$ & $\begin{array}{l}\text { 簐士 } \\
\text { 婁間 } \\
\text { の }\end{array}$ & & 庭 & $\begin{array}{l}\text { 山 } \\
\text { 中 }\end{array}$ & $\begin{array}{l}\text { 嵖 } \\
\text { 道 }\end{array}$ & $\begin{array}{l}\text { 山出 } \\
\text { の鼻 }\end{array}$ & $\begin{array}{l}\text { 山草 } \\
\text { の原 }\end{array}$ & $\begin{array}{l}\text { 住庭 } \\
\text { 居 } \\
\text { の }\end{array}$ & 枺 & $M$ & III & $\begin{array}{l}\text { 川 } \\
\text { 舟 }\end{array}$ & 町 & $\begin{array}{l}\text { 茶 } \\
\text { 店 }\end{array}$ & $\begin{array}{l}\text { プト1 } \\
\text { ラフム } \\
\text { ッ }\end{array}$ \\
\hline- & $\curvearrowleft$ & $\neg$ & \ulcorner & $m$ & 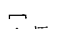 & - & - & $\curvearrowleft$ & $\curvearrowleft$ & - & $\curvearrowleft$ & $\neg$ & - & - & $\neg$ & $\curvearrowleft$ & - & $\neg$ & $\neg$ & $\sim$ & $\curvearrowleft$ & $\curvearrowleft$ & - \\
\hline 老藏 & 床趣 & 無 & 鏡淡 & 二今 & 向挨 & 山急 & の垣 & 石眼 & 庫余 & & 星 静耀 & 門此 & 三背 & 山入 & ニな & 岨 士 & 立白 & 岸一 & 归水 & 女。 & 舟 腹 & 向写 & 新余 \\
\hline 人せ & はは & $w$ & がき & 間で & 側口 & 里に & つの & 秱に & 車は & いに & こかき & を所 & 丁中 & のb & 人ま & 道䅉 & て鞘 & に行 & 幅の & はえ & はを & 的生 & rも \\
\hline のた & 平落 & - & 池影 & 稌6 & のて & のう & そ向 & を落 & に自 & & 七なを & 出に & 程に & 出 6 & はめ & のの & 切の & はの & は上 & 黑 . & 渐返 & の㛿 & 谙飞 \\
\hline 部茶 & 床占 & & へが & b少 & 景、 & 椸れ & りは & 行D & 入分 & 月け & †庭放 & $\tau \&$ & 上は & 鼻の & 春加 & 登下 & つ短 & 大船 & あ迄 & 2 & $<L$ & 床を & がと \\
\hline 屋 碗 & を付 & & 来、 & を々 & 色半 & にL & 山墓 & きる & ろの & 民る & 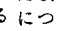 & 市 & る光 & のは & Q $\mathrm{L}$ & りは & た刀 & きは & ま響 & て方 & 町 $\tau$ & 几出 & LR \\
\hline はを & 镜き & & $\tau \hbar$ & 爪赤 & は分 & 乘く & 門場 & 盡の & 吓 & p皘 & 䝷 ’。 & 左る & とる & 平言 & 山さ & 口す & 障が & な静 & $n<$ & 向角 & ら飛 & $E L$ & て立 \\
\hline$\cdot \mathrm{T}$ & の過 & & 見ら & 先い & 冫以 & とな & をで & くは & 庫，駄 & & 松漁 & へは & 、海 & なは & 。 & へぐ & 子嚳 & 柳か & 兴。 & をは & Ls & はて & b \\
\hline 余覓 & 粎ぎ & & $3 n$ & 上様 & あ上 & $\tau 0$ & 遺あ & し 花 & 妻を & .5 & らの火 & 切蜜 & 向を & 所主 & 背凡 & 出筫 & をの & がに & <何 & むあ & w。 & $=\cdot$ & 白て \\
\hline がに & $に \tau$ & & ${ }^{\circ}$ 古 & がな & 机水 & そて & 入ら & てば & は丁 & とj & 影は & れ柑 & 宗負 & へれ & $k \tau$ & て湘 & '上 & あ太 & なを & $<\omega$ & な家 & $\vec{\Lambda}=$ & <居 \\
\hline 室 机 & 京寧 & & 観ら & i) 氣 & なの & $\therefore$ & つj & 左加 & 明䅎 & 障 & 。が明 & るの & $に \tau$ & 出 6 & 'か3 & 畠 & 汃 & る公 & い唄 & 。浐 & か鴨 & 汃 & 光る \\
\hline のの & きろ & & 海り & にが & り面 & 万登 & $\tau^{0}$ & $\sim \eta$ & it & 子七 & - 落㳚 & とみ & 白な & た知 & 春好 & すで & ら輁 & ○望 & $\circ$ 市 & 川で & へが & けの & $3^{\circ}$ \\
\hline 廊上 & 込㓌 & & 寺と & 登す & でへ & 齿り & “左 & 折で & 放揃 & を & ちす & ' & 壁る & . & の蛽 & くあ & りが & 下の & 底の & 緣す & 通加 & 个姿 & 珴 \\
\hline 下へ & 几氣 & & の其 & るる & 略乘 & <出 & 見は & れあ & Lへ & & $3^{\circ}$ & す思 & $\sigma^{\circ}$ & 北た & 海題 & $\cdot 3$ & $\varepsilon \eta$ & に前 & はや & は。 & 入あ & 居を & 路 \\
\hline をな & でで & & 軎間 & $\because 0$ & 䋊 & ${ }^{\circ} \mathrm{L}$ & 当本 & 万る & $\tau 3$ & it & ○一 & ぐは & $-\bullet$ & 側青 & をで & 右。 & 開出 & 小を & 浅ら & wー & るか & 万描 & $\sigma$ \\
\hline 右ら & ‘あ & & 道に & 頭ま & まだ & 観た & と堂 & $\varepsilon^{0}$ & あ。 & 3 & 啄 & 岨れ & 栗 & は海 & 前あ & $k \sqcup$ & it & さ通 & $w-$ & $D^{\prime}$ & 。 & 。 & 上 \\
\hline へベ & 錆る & & の見 & のた & oL & 海の & ‘だ & 庫 & $3^{2}$ & 0 & $<$ & 道る & t5 & 翠で & kb & 折 & $b^{\circ}$ & なり & 。向 & か & 腰鳴 & 等取 & を \\
\hline 突る & 氣。 & & 'z & 上落 & $\tau \tau$ & 寺で & 展。 & 表 & $\circ$ & 飛 & の & $\partial^{\circ}$ & 見 & りあ & $\because 0$ & れ & 는 & 船超 & 流分 & ' & 障 く & lo & $\checkmark$ \\
\hline き。 & t & & 杉万 & にち & ஆか & のあ & いー & ר & $\vdots$ & U & 海 & $\therefore-$ & $\dot{\lambda}$ & をる & $\vdots$ 一 & $\tau$ & 内 & 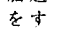 & れ5 & 水 & 子。 & くた & 文 \\
\hline 當し & 吹 & & の。 & はた & るる & 石る & 庫 & 出 & & 石 & は & き & $\tilde{3}$ & 畐。 & & : & は & 晖。 & はぬ & r & に一 & $\vdots$ & 明 \\
\hline 0 & $w$ & & 問一 & $\vdots^{\circ}$ & $\circ 0$ & 段。 & 軎 & 3 & & $x^{5}$ & & の & $\circ$ & t & & 又 & 空 & いー & $\phi^{\circ}$ & す & 御 & - & の \\
\hline$\vdots$ & $\vdots$ & & $\vdots$ & - & $\vdots \longleftarrow$ & $\vdots$ & $\vdots$ & $\vdots$ & & $\vdots$ & $\vdots$ & $\vdots$ & $\vdots$ & $\vdots$ & & $\vdots$ & $\vdots$ & $\vdots$ & $\vdots \smile$ & $\vdots$ & $\vdots$ & & $\vdots$ \\
\hline
\end{tabular}

る「川・駅」という現害なる場所が同じく絵画的言語空間として選 ばれている。場所としては全九筒所（「那古井の温泉場 I ・II」を 一緒にする場合は八筒所である。）が描写されている。構成とテー一 マから見ると、濑石には場所の設定において相対立する二種の設定 の仕方を取っていると思える。その一つは自然と関わる場所の選択 であり、他の一つは現害の場所の選択である。特に前者の場所は、 全章に渡って上げられている。それは「草枕』の語り手である一人 の画工（濑石と称する。以下同し。）が図の題材を求めて旅に出る という行為とそのために設定される尤もなる場所である。また自然 の場所の選択は、現実社会に対する視点を根本的に改革するために まず漱石自身の人生探究という点からみることと通ずる。『草枕 」の文体の描写内容加見ると、自然の奇物そのものからは「を 樂ませつ〉」11「「見るものも聞くものも面白い」12）「苦勞も心 配も伴はわぬ」13) という心が得られることであり、更に自然の本 然たる姿を吸収することでそこから非八情14) 的な世界が追求でき ると思ったからである。自然を通して「眼が醒め」15)「愉快」16 ) だという自己の内面意識が開放される心情が成就され得るのであ る。このような心の変化は、自己の梁層からの動きの現われであり

「自然」から生み出されるものである。心の動きとは「吾人の性 情を瞬刻に陶治して酹乎として醇なる詩境に入らしをる」17)とい う所謂自然を素材とした純粋なる詩情の精神にかかわることであっ た。その上「すこしの間でも非人情の天地に逍遙したい」18）とい う元の目的が得られることでもある。このような自然からの純粋な 出来事は、次に「境を解脱する」19）という自覚へと導かせる。こ れらは凡て自然そのものが持つ力であると共に、その力を自らのも のに内部化させる。その結果、今まで自己にはなかった精神を自覚 することで、新たに衝突するさまさまな緊張の形態をどのように構 築していくかというーつつの試みるところになる。言わば内面的な深 化にふさわしい所として選比ているのである。この様に内なる自 己へと向きをとることは、前述した様に「世間的」に対する「出世
間的」な意味を表わし、自然を通して本然たる自己形象の世界を形 つくるためである。これこそ漱石の自己の姿であり、求める芸術思 想と通ずるものである。自然への旅のなかで得られる経験を一つず つ潜りながら認識を深化させまた続けていき、最後に图として得よ うと試み、ついに望んだ「胸中の畫面」20）が成就する。この濑石の 思想の絵画が表われる場所が、後者の現実の場所なのである。言い 変えれば、濑石は自己の思考世界を二つのありあわせの場所を介し て示しており、内面世界の図式を言語を用いて絵画化するという手 法を通して空間化し、その空間によって自己の立場を徐々に磪立し ていくのである。

言語によるものではあるが、自己の内面世界を具体的な形をとる 絵画として表現するということは、濑石が何を見ており、思考し ているかを形で表わすことでもある。またこの様なことは濑石自身 に確認せしめると同時に、他人の視界にもさらされるような形とし て示す表現活動であるといえる。いわは、造形的な把握の展開とし て絵画的な表現とは、濑石の思考世界て把握されつつある私的な空 間を、他者にもその空間を見せる公的な空間1）として造るものであ るといえる。それに他者に見せる絵画の形には、それが現出してい る場所を自己のあるべき現害の場所として見て定めなければならな い。即ち、絵画そのものには「色、形、調子が出来て、自分の心が

あ、此所に居ななと、忽ち自己を認識する様にかいなければなら ない 22のである。ここで絵画の形を構成する人の心的状態は絵画 を構成する上に重大な影響を与えるものとして認識し、自己の内面 的かつ深層的実存への共感を絵画に包含することで絵画が表わ寸形 に自己の意識を出現させるのである。絵画の形を表層の構造として そして絵画が生じてくる基盤である深みを深層の構造とするなら ば、濑石が『草枕』のなかで描く言語を用いた絵画は、自然の場所 と自然を表現する表層の構造と、出来事の背後にある思考、即方自 己認識という哚層の構造とを雨方包含古る構図として理解され得る のである。 


\section{3. 絵画的君語空間の分類}

前述で示したように絵画的言語空間の対象となる場所は主に自然 があるところであるからか、描写された絵画的空間ははじめに山水 の風褁図として多く見られる。「山路、山中、路、山と山の間、庭 那古井と温泉場、那古井の浜、過去の庭、鏡が池、池の水、観海 寺の石段、山門、岨道、山の出鼻、住居の庭、川、川舟」などがそ うである。山、石、木、雨、雲、霧、松、孔雀…などの自然の姿を 描写する風景図は、もともと東洋の文人達の間で好用されたもので あり、「詩が有声の画であれは、画は無声の詩である」23)とされ るほど、素材と描かれた山水から読み取る意味に重点を置いたもの である。同しく「草枕」でもこのような景色を「一幅の畫として觀

一卷の詩として讀む」24) と描写している。自然の素材が単に視 覚的な感覚物として情緒的な追求のために描かれるものではなく、 表面には現われないその背後に㩊れている意を表わすものである。 主人公である画工はこれらの素材を通して自分自身に近い声として 意識する。即ち自己の内面を写し取ろうと試みた風景図であるとい える。従ってここにおけりる風景は、前述した心の変化を一つの絵画 的空間として出現させるための一つの对象であることを意味し、逆 にいえば一つの風景図という形から目に見える形象としての自己内 面の空間図を描いたものである。

次に多く見られる絵画的言語空間は、人物を含む図である。「茶 屋、茶屋の前、路秝の部屋、二階の欄干、幅三尺の空間、風呂場、 山の草原、茶店」の絵画的言語空間に描かれた凡ての人物は、画工 にとって絵画の素材となる。「これから逢ふ人物を一百姓も、町入 も、村役場の書記も、爺さんも婆さんも一悉く大自然の點景として 描き出されたものと假定して取こな」25) すと語られている。人を 自然と同しく报うことは、画工が入事を離れて自然に入るという意 味に用いられる。現実の人を相手にすると知性が動いてしまって純 粋たるものの見方を妨げ、その現害のものに負㠹るからである。こ のようなことは八の純人情が読めないことを意味し、又純秝な美と して見ることができないことをも意味する。従って、人情から超然 とし、それにわずらわされぬこととして报うのである。言い換えれ ば、これは自己の知性を静めることを意味し、一種の自己の悟りと 通ずることである。主人公である画工は人物を美しい自然の一つと して見て、人物の動きを自分とは離れたものとして観察するために 絵画の枠のなかにはある。即ち絵画のなかの人物として被等を見る のである。そうすることで面工は客锶的な描写態度をとることがで きると共に、これこそ現実では取りにくい絵画表現になるのである 。それは平静に眺めることができるという心的境位に至ることを㕵 んでいた画工の心の構造を表わしたものでもある。

その他に見られるものは、室内図と静物図がある。室内図として は「茶屋、過去の宿、橡側、風呂場、老八の部屋、庫裹の土間、床 」のことであり、静物図としては「温泉場の宿、座僌、床、庫裹の 前」がある。これらは、前述の二つの図が素材そのものを通して深 層の詩的美的な表現を表わすという構図とは違って、素材の相互関 倸、それらの媇置、形、或いは模様などの具体性を空間に表わして いる。いわは素材の写実的な表現を用いた空間構図を取っていると いえる。

ここで室内図の例として、一つの絵画的言語空間の表現句を取り 上げることにする。
「“执い”䠘を掛计たが返事がない。

郫下から奥を覞くと煤けた障子が立て切つてある。向ふ㑡は見えない。五六足 の草鞋が森しさうに庇から吊されて，屈託氣にふらふらと採执る。下に䭾菓子 の箱が三つ許り並んで、そはに五厘銭と文久銭が散らぱつて居る。

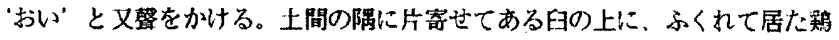

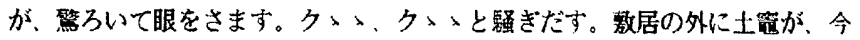
しがたの雨に濡れて、半分程色が變つてる上に、墨黑な茶鉒がかけてあるが、 土の茶蓥功、銀の茶菳かかからない。幸ひ下は焚きつけてある。

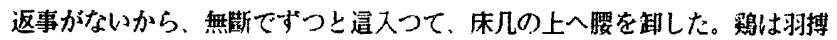

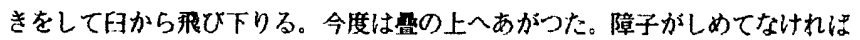

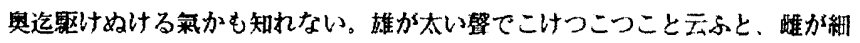
い韾てけ、つこつこと云ふ。丸で余を狐か狗の様に考へてかるらしい。床几の 上には一升枅程な䅉草盆が闌静に控へて，中にはとぐろを捲いた線香が、日の 移るのを知らぬ顔で、顔る㤵长に爅つて居る。雨は次第に収まる。

しばらくすると、奥の方から足音がして、煤けた障子がさらりと開く。なか ×ら一人の婆さんが出る。126)

例文における表現内容から、図は「剘下」、「土間」、「奥」の三 つの空間から構成されているのが分かる。「軒下」は外部のところ を、「土間」、「奥」枘部のところを描写している。またそれぞ れの空間にお圢る素材は、「五六足の草鞋、䭾菓子の箱、五厘銭と

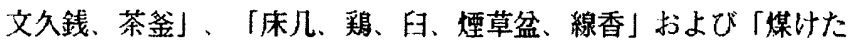
障子、嘼」であり、物体の姿が忠実に描かれている。各々の素材は

それ自体としては個別的であり、素材相互間には何の関倸も持た ないものとして視覚的に描写されている。しかし描写を詳緗に分析 すれは、素材は互いに力を持って関連し合い、三つの空間をつない でいるのが分かる。外部にある庇に吊られている草鞋とその下にあ る䭾菓子の箱は、空間を「上一下」の関俰に結ぶ。そばにある五厘 銭と文久銭、そして同しく數居の周辺にある土䀂の茶鉒は、空間を さらに「そば」へと広げる。また外部を内部へと繁ぐ素材としては

「薣」と同時に視覚上の「覩く」と「無断でずつと這入」るとい う行為で示される。外られた内・外空間は、今度は土間の隅にい

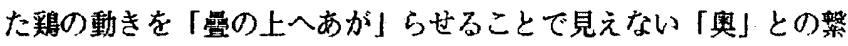
ぎを暗示し、ついに障子が開く」ことで完全に三つの空間は一つ になるのである。こうして提示されたすべての素材の写実的描写に は、空間を建築的に捉えかつ县くこことで、空間の統一ーという意味を 隠していたのである。つまり多様な素材の具体的な表現は、一つの 構図を成立させていくものとして、それに一つの決定的な意味を䓕 き出す素材として捉えられる。そしてそれそれ周辺に散在し存在す る素材は、統一を造るため中心的な素材へと表出していくのである こここで絵画的言語空間は、空間搆成あるいは造形構成の調和をな す素材の統一へという新たな輔成の意味を示しているのである。

引き続き静物図の例として、その絵画的言語空間の表現句を取り 上げる (表一1、24 番の絵画的言語空間)。

「床は平床を鏡の様にふきき込んで、錆氣を吹いた古銅瓶には、木苚を二尺の高

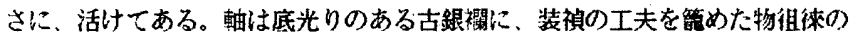
大幅である。絹地ではないが、多小の時代がついて居るから、字の吅拙に譣な く、紙の色が周圈のき扎地とよく調和して見える。あの銀襴も織りたては，あ れ程のゆかしさも無かつたらうに、彩色が䘰せて、金絲がんて、華麗な所が 滅り込んで、啮い所がせり出して，あんない〉調子になつたのだと思ふ。焦茶

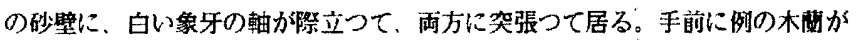
ふわりと浮き出されて居る外は，床全體の趣は落ち付き過きて察ろ陰氣である . 1 27) 
例文の表現内容から、図は「床」の空間を描写している。また「床 」を構成している静物としては、「古銅瓶には、木蘭」、「軸」の 二つの素材だけである。二つの素材は、「侏」という小さな空間の なかで単独のものではなく、並存されたエレメントであることが分 かる。まず「休」の手前には「古銅瓶には、木蘭」が位置されてお り、木蘭の高さは「二尺」に至ってある。その後面には「床」の「 焦茶の砂壁」で、又この壁には「軸」が掛计られている。「平床を 鏡の様に吹き込んで」あり空間構造上三面が壁に囲まれる「床」は 先の二つの素材によって空間が「手前（前景）一後（後贯）」に 並ぶ形を取る。手前と後の距離は短いものとして極端的に狭い空間 であるが、二つの素材による奥行きある空間の形が内部的に整えら れている。

次に、床の空間に配䈯されている各素材に対する表現は、究めて 織練であることが分かる。特に、「軸」に対する描写は明確なその 性貿の価値を示している。「物组徕の大幅」で、「古銀襴」を下地 の紙にしてあり、その状態か時代とともにして「彩色が祓せて」、

「華麗な所が隇り込んで」、「涵い所がせり出し」ており、「い》 調子になつた」という洗練された芸術品の極致をわきまえている。 またもう一つの素材である蘭を活ける花瓶に対しても「錆氣を吹 いた」ものである「古銅瓶」にすることで、時代という時間をとも にしたものとして示している。この二つの素材は「軸」が表わす性 質と調和している。二つの素材は床の空間を飾るものでありながら そもそもそれらの性筫は異なる静物である。相違なるものを一つ の空間内に配置させることは、一般的に不均整をうみ出す動因にな り得るが、床の空間のなかでこの様な異質的な静物を並存させるこ とが可能だったのは、先述した素材の位置による空間の整理とそれ に各素材が表出する侘びた風情の一致におういて、各々の素材が独立 性から調和をなす方向へと動く静物図が見事に表現されたからであ る。室内図で述べたように、静物図においても各素材は一つの構図 を図るための働きをしていたのである。次の語りである「床全體の 趣は落ち付き過ぎて當乃陰氣である」という表現をかりて、絵画的 言語空間である「床」の静物図は帰結されるのである。

\section{4. 絵画的言萿空間における建築的構图}

抽出した絵画的言語空間の表現呴から素材による配置楆成と空間 形成の方法について述べる。

\section{4一1. 輪郭について}

絵画的言語空間のなかで六つの空間はその輪郭を明確に示すもの として取り上げら礼る。それらの表現句は（表一1）における番号 10、13、15、17、19、32 に当たる空間である。絵面的言語空間の外 郭線としてくぎり取られる表現句が䔩み取れる。各表現を見ると、

「障子をあけたら」、「右側の障子をあけて」、「左り側の密をあ ける」、「入口の襖を開たら」、「開计放つ幅三尺の空間」、「障 子をあける」がそれである。障子、空或い性裸をあけ見える最色 は、障子、空、襖を一つの縁として、或いは一つのウォリュ一ムの シルエットを示す外郭線として取られる。この空間の輪郭を具体的 に大きさまで確害に表現しているのが「幅三尺の空間」というもの である。

絵画的空間にお计万外郭線は、外部風量を限るものとして、風景 の中からそれをきりとる役割をつとめている。形成された風景の一
部分は示そうとする絵画を想像において全体として代表する。即ち 輪郭そのなかの空間という部分が全体を象徽するのである。ここで 空間形成に拈ける空間のかたちは輪郭という空間の枠によって制限 が加えられるが、そこに見える空間は寧ろ輪郭によって空間意識の 深さを内在させるといえる。

同しく絵画的急語空間における輪郭の決め方を他の方法で表わし ているものがある。それは空間の範囲あるいは方位、方向を決める ものとしての「上一下」と「右一左」の形成方法である。先述した 輪郭の形成が、空間における全体の大きさ、いか济外郭を示す形成 方法であるというならば、「上一下」および「右一左」の形成は空 間を構成する素材によるものとして、素材の形と状態を表わす表現 から輪郭を探る形成方法であるといえる。抽出した表現句のなかで 先の六つの空間を除いた殆んどの絵画的言語空間には、この輪郭の 決め方が見られるのである。

ここで「上一下」と「右一左」が表現されている例文（表一1に捛 什る番号 27)をあげてみることにする。

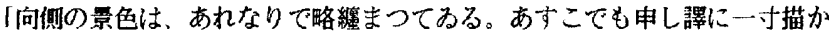
う。一丈䍱りの蒼黑い岩が、䔬直に池の底加突き出して、浱き水の折れ曲る 角に、嵯ヶと構へる右側には、挒の能笹が断崖の上から水際まで、一寸の隙間 なく藂生してるる。上には三抱程の大きな松か、若鳥にからま机た幹を、斜め に㨝つて，半分以上水の面に乘り出してるる。」28)

表現から空間の素材になるものを抜き出すと、「岩、池の水、熊䈎 松」が主に使われているのが読み取れる。これらの素材から絵画 的言語空間における「上一下」および「右一左」を示す表現们をも う一度詳細に抽出すると、「一丈餘りの荅黒い岩が、真直に池の底 から突き出して」留えている岩の形、また「斷崖の上から水際まで 一寸の腙間なく丵生してみる」熊笹の状熊、「上には三抱程の大 きな」松、などが空間の「上」に当たる輪郭として読み取れる。そ して「濃き水の折れ曲る角」、「水の面」、「水際」として池の水 の素材が広がっている。また「幹を、斜めに挨つて、半分以上水の 面に乘り出してみる」松の形状などが空間にお引ける「下」の輪郭を 指示するものとして読み取れる。このようにして、「鏡が池」の空 間は「上一下」の輪郭を形成するのである。

もう一つの「右一左」の輪郭は、濃き池の水が空間として表現さ れているなかで、水が折れ曲る角の場所そこ江方向として「右側」 である。さらにそこには岩という素材が位置されており、熊笹が丵 生し大きな松が斜めに挨っているなどの素材がすべて「右」に集ま っている。その反对である「左」に関しては描写はない。只池の水 が下の空間に広げられている状驡から、「左」は素材として池の水 だけが描かれていると想像することが出来る。いわば、「左」を余 白の空間として残して置くことで「右一左」の輪郭は表現上対比さ れる素材構成によって均等に分けられる。しかし、ここで池の水は 切れることなく「右」へと再びもどされ左・右がつながる形態とし て緭結されることを暗示するのである。

この様なことから「上一下」、「右一左」は輪郭の形成を決めて 一の限られた空間決定へと進んでいく形成方法そのものであると いえる。輪郭における空間の全方位、全方向にわたって素材は平面 的なものから立体的ウォリュ一ムを持つものへと全空間において集 まり、一つの絵画的言語空間を建築的な配置として捉えるという形 
成が出現される。つまり言語による平面的な各々の素材を立体的な 空間の形成として造り替えるという建築的空間の考えが含まれてい ることが明らかになる。

\section{4-2. 層状椿图について}

絵画的言語空間に見られるもう一つの空間形成は、空間の層状で ある。前述した空間の構成素材が位置する面を一つの場面或いは空 間として䍿識する。各々の空間として場面を描写した文章のまとま りを一つの層として捉えるとき、多くの層が見られる。またその多 くの層からは、ある構図を見い出すことができる。それは層状構図 である。曾通よく視覚で捉えられるものとしてきれいに揃っている 層状があり、不規則でかつ分散されているような層状もある。各々 の層は断片的な視点の移動や動きによって横断して行き、そこには 一つ一つの層の重なり合いという重層の空間構図が見えてくる。こ のような層状構図は空間を展開させるという一つの空間造りの表現 である。(表一1）の絵画的言語空間は言語で表現されているの で、視覚 (視点) の焦点やその動きを確定し難い。ここで、「文学 作品に呈示される空間は、呈示される対象物と共に呈示されるので あり、この呈示される空間は作中で対象物を知覚する主体の視点の 定位にしたがって表現される」29) というインカルテテン一の文学空 間の定義を適用する。すると、文学における文章上の語り手（二話 し手）の視点に着目することになり、内容上語り手の視点が定位し ている位置をここでは視点の始まりとする。語り手の視点が動きな がら他の位置にある対象物（上述の構成素材に当たる。）について 語るとき、その対象物が定位している位置は語り手が定位するとこ ろとは違うもう一つ展開された空間層として読み取ることになる。 空間層が展開する方法は、語り手の視点を中心としてこれを一つの 軸とするとき、対象となる空間は中心軸に直交するもう一つの軸に なる。この相互直交する二つの軸によって、空間のなかで層の配列 は繀型の構図と横型の構図、中心型の構図を取るのである。

ここで三つの配列搆図をそれそれの例文から見ることにする。 ず、縦型30)による構図の例文を取り上げる。

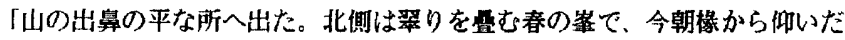
あたりかも知れない。南側には焼野とも云ふべき地知が幅半丁程廣がつて、 末は崩れた崖となる。崖の下は今すきた蜜相山で、踦いで向を見れは、眼に 入るものは言はずも知れた青海である。」31)

表現から一つの層と考えられる表現句を抜き出すと、「翠りを畾む 春の峑」、「山の出鼻の平な所」、「焼野とも云ふべき地勢が幅半 丁程廣がつて」、「崖」、「蜜柑山、「青海」の六つの層が読み 取れる。これらの層は面というより各々帯状として空間が連なって いるといえる。北側にある春の峯から南側の青海に至るまで六つの 空間層は、南北に一つの線を引くように維方向に連なっている。こ のような構図の場合、風罢には横より維に連なる空間層によって奥 行が与えられる遠近法が見られる。しかも視覚上一目で六つの空間 層の全体が見渡され、一つの絵画のもとに対象を捉えることができ る。いわば全体の空間を立体的な意識を持つ層状として、かつ储瞰 的に表現される層状構図を取るのである。出累の平な所は、一つの 精神が安住する落ち着く所として保䍌され、ここから視点は出発し 周囲の空間展開へと移動し始める。その近量には山の峯がそびえた
ち、中景には焼野、崖、蜜柑山が広がる。そして岸と䖝柑山を越し た所に遠景である青海を置く。風景の現場における幾つかの層を俯 瞰という構図法を取ることで全体の空間は客観性を持ちながら、風 景の存在を保持し、同時に安定したものとして表現するのである。 従ってここでの層状構図は、遠近法的パースペクティウとして造ら れる一つの建築図式に近いものであるといえる。

次は横型32）による層状構図の例文を取り上げることにする。

「のつそり山門を這入つて、見ると、廣い庫裹も本堂も、がらんとして、人影 は丸でない。

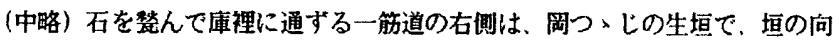
は墓場であらう。左は本堂だ。」33)

ここです表現から層となる表現句を抜き出すと、「一筋道」、「生 垣」、「墓場」、「本堂」の四つの層が呓み取れる。「一筋道」は 山門から庫裹を結ぶ直線的な中心軸になっており焦点を示す。そ の左右に「本堂」と「生垣」、「墓場」が横に並べられる構図であ る。このような構図は、空間層が前後関係におういてよるものではな く、横への平行関僄において層を均衡に捉えることで「一筋道」の 焦点を真ん中に置きその雨方へと二つの層の分けが行なわれるもの である。しかし「一筋道」は、全体空間における中心であり焦点と いうことで左右の層をすべて収束していく。絵画的言語空間におい て「一筋道」の終着である庫裡は実際表われなく、ただ一筋道」 だけが表現されていることで、ここでの焦点の先は遠さかるにつれ てその本質的な意昧は失われるといえる（只、語りの内容上庫裡へ 䇣がるという概念は引き続き存在する。）。すなわち「一笳道」は 左右の層を収束するが、それを焦点の始まり㑡から向うの奥へと「 一筋道」が進んで行くにつれて左右の層状構図を消失へと向かかせ る。結局、奥行ある層状をなしてあるが、それが視覚的には左右と いう横への平行的な層状として現われる。一つ一つの立体性を持つ 層は平行化して表現されるといえる。このような層状構図は左右の 中心に視点を置き奥行きある空間をつくる透視图法を見せるが、左 右の空間表現による層状の横への広がりも見せる。透視図法の立体 空間造りを基にして、それに左右の平行的な平面が新たに構築され るという有機化した平面への空間造りであるといえる。

三つ目の中心型34）の層状構図の例文を取り上げる。

「小供の時分、門前に萬屋と云ふ酒屋があつて（中略）余は庭へ出る。茶畠十 坪狳りを前に掏へて、三本の松が、客間の果㑡に並んて居る。此松は周り一尺 のある大きな樹で、面白い事に、三本寄つて、始めて趋のある恰好を形つくて なた。小供心に此松を見ると好い心持になる。松の下に黒くさひた鐵燈籠が名 の知れ好赤石の上に、いつ見ても、わからず屋の頑固窃の様にかたく坐つて居 る。余は此嬁筑を見詰めるのが大好きであつた。燈䈗の前後には，苔深き地の 抽いて、名の知らぬ春の草が、浮世の風を知らぬ顔に猲り匂ふて、獨り然しん で居る。余は此草のなかに、赦かに睖を容る 席を見出して、しつと、しゃか むのが此時分の痛であつた。此三本の松の下に、此燈籍を晛めて、此草の香を 臭いで、さうして御倉さんの長唄を遠くから閣くのが、當時の日課であつた。 135)

表現から層となる場面を抜き出して見ると、「庭」、「茶畠十坪」 「三本の松」、「容間」、「鐵燈籠は赤石の上」、「苔深き地」 「春の草」、「㮏を容る席」の八つの層が読み取れる。この八つ の空間層のなかで中心になるものは、わずかな小さい空間である「 
膝を容る、席」なのである。それにこの中心層は、個人の存在を主 張するところであるのが読み取れる。自己の心は、「好い心持にな る」、「しつと、しゃがむのが此時分の癖」、「當時の日課」であ ったという語りから、主観性を帯びた感情的な空間であることを表 わし、「此三本の松」、「此燈籠」、「此草」と自己主体の特定な 構えとしての空間であることをも暗示する。中心になる「㮏を容る 、席」をめぐってその周辺に置かれている他の層は、次々に一つの 空間層を捉える構造を示しながら、八つの空間層のなかで「膝を容 る、席」が中心になるように取っている。すなわち「茶皇十坪」と 「客間」を一番外側に置き、次は「庭」を置く。その次には庭のな かで「三本の松」を置き、「鐵燈䇺は赫石の上」、「苦梁き地」、 「春の草」がそれぞれ「三本の松」の周囲に構えられる。そしてこ のなかで最後の中心になる層が置かれるのである。いわば、八つの 空間層は周辺的なものから次々と具体的な空間へと向いていく構図 を見せる。中央の焦点に向くほど自分の主体を認識する密度ある。. つの圧縮される空間造りを上げているといえる。このような層状構 図は、逆にいえば中心を原点としてそこから建物が放射状に配列さ れる遠心的な空間棰図として考えられる。しかしここでの中心型の 構図は中心に近付く方向をもつ集中形式、いわば求心人と表出して いく構図の成立である。

\section{5. 結び}

「草枕」の文句を再引用して見ると、絵画は「空間的なる繪畫上 の要件を充たしさへすれば、言語を以て描き得る」36)ものとして 、建築にお忛る絵画として言語的素材を見たてたのである。すなわ ち、言語的表現による絵画から建築的造形空間の構想を読み取るこ とを試みた。ここにおいて、言語という单語およびその表現は絵を 描くための素材になる要素であり、これを用いて自己の内面意識を 絵画で表わす形式を取っている。自己意識を絵画化すること流その 意識を表に表現することを意味し、見せることである。即ち、言語 によって描かれた絵画は自己を表現する手段であり、その表晛の過 程では情緒的表現を経て芸術的な構成へ、そして空間的関係へと展 開して行く。いわば、言語による絵画を用いて内面意識を空間北さ せることであり、自分の意識を広げる害の空間構築の可能性を探る 根源的な意義を持つ。このように八間の精神を空間化して表現する ことは、彫刻、建築など造形のあらゆる分野で求められる構造であ る。

「草枕』から絵画的言語空間を分類した結果、風景図と人物図、 室内図と静物図の四つの種類が得られた。風景図と八物図は、自然 から精神的な源となる自己の思考を得ることで思考空間を絵画とい う視覚的に見える形で取る構図であった。そして室内図と静物図は 前の二つの図とは違って絵画的言語空間を構成する言語素材の形 模様、その配置などが空間のなかで一つの構図をはかるための㗢 きをし、またその過程のなかで、各々の素材は「外一内一奥」、「 前一後」、「上一下」の構成で空間内に調和と統一を成す建築的発 想を取る構図であった。また、絵画的言語空間におりる輪郭の決め 方からも「上一下」、「右一左」という建築空間の範囲或いは方向 方位を決方方法を取っている。そして、構成素材の配列から考 察した三つの層状空間構図である縦型、横型、中心型の空間形成は 平面的な素材を一つずつ分析しその元の構筑を再配列というレへ
ルで試みることで言語による絵画の全体空間は立体的な意識をもつ ものとして、いいかえれば遠近法或いは透視図法による建築的な空 間造りとなっているのである。

『草枕』に拉ける一つの造形空間の造りには、言語による建築的 空間造りの思考が潜んであり、または建築的発想が絵画的言語空間 に浸透しているといえる。このようなことは、「草珫』が文学では あるが、漱石は文学を超える概念へと導く思考を持方、さらに文学 的な絵画を通して一つの造形空間を造り、そこに建築的空間構図の 方法を考えていたと言えよう。今後の課題として、『草枕」の絵画 的言語表現から絵画空間の内的概念の構成を考察し、そこに执いて 言語による建築的空間図式の可能性をさらに注意深く考察されなく てはならないと思われる。

\section{註}

1)「草枕」：明治三十九年、新小説（春場堂より1889年創刊）に発表。本 研筧は、作品の原文を尊重守る見地に立方，岩波書店の昭和二十二年度第一刷 発行以後のものである、昭和二十五年第二刷「濑石全集」第三巻を用いる。文 学者 Boulton (参考文献) が分離している小説の視点を「草枕」に適用寸ると

「余」という三人妳を使って作家が語る第一の視点を用いる一人称の小説で ある。

2）坂本浩：「草枕」の制作意図、夏目漱石一作品の深層世界一、明治書院 昭和54、pp.85、再引用

3）夏目濑石：『草珫・二百十日·野分』、濑石全集第三巻、岩波書店、昭 和二十五年 第二刷発行、草枕・一章、pp.13、十三行

4) 同上一章, pp.12、三行

5) 同上一章. pp.6、五行

6) 同上一章、 $p p, 6$ 、九行

7) 同上十二章、pp.171、六行

8) 同上十二章、pp.183、三～四行

9) 同上一章、pp.6、二行

10）（表一1）に抽出した絵画的言語空間の表現句は、絵画的表現の文章を一 つの段落の意味ではなく、図の場面として内容か繋がる文章のまとまりとして 抽出した。

11）夏目濑石：前揭書、一章、pp.11、十一行

12) 同上一章、pp.11、六行

13) 同上一章, pp.11、十一行

14）同上一章、pp.13、十三行

15) 同上一章. pp.9、八行

16）同上一章、pp.9、十行

17) 同上一章、pp.14、六行

18）同上一章、pp.11、十二行

19) 同上一章、pp.11、十二行

20) 同上十三章、pp.198、十二行

21）公的な空間：絵画的言語表現を用いた『草枕」を通して珫む人に濑石は自 分の芸術思想を表わすことを意味する。

22）夏目濑石：前揭書、六章、pp.90、九一十行

23）増田知也：「家と庭の風奇一日本住宅の空間論的考察」，十カニシヤ出版 $\mathrm{pp}, 216$ 、再引用

24）夏目濑石：前揭書、一章.pp.11、八行

25）同上一章、pp.16、三～四行

26）同上 二章、pp.19、二 十三行、pp.20、五行

27) 同上八章、pp.116、十一十三行、pp.117、一〜三行

28）同上十章. pp.148、十行〜 pp.149、一行 
29）ロマン・インカルルン：『文学的芸術作品」、第35飭、钴草書层、1982 30）(表一1）における絵画的言語空間のなかで、維型の構図をとっている空 間は、番号1，4，5、9、10、13、15、16、17、18、23、26、27、28，30、31 、32、33、34、35、37、38、41 てある。

31）同上十三章、pp.174、六一八行

32）（表一1）における脍画的言語空間のなかで、横型の構図をとっている空 間は、番号3、7、11、19、24、25、29、42であある。

33）同上十一章、pp.152、六行〜pp.154、七行

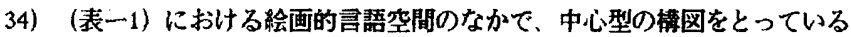
空間は、番号2、6、12、20、22、24、39、40、43、44 である。

35）同上 七章、pp.102、八行 pp.103、四行

36)同上 六章, pp.92、九 十行

参考文萳

1）徐貴潄：「境界的空間が持つ意味についての考察一濑石の゙草枕゙に見る 四つの境界的空間一」、日本建築学会計画系論文集、第485号、pp.227-235 、1996年7月

2) 徐贵淑：「文学作品の空間描写における空間檽成の部分と全体の関伯に関 寸る研究」、日本建筑学会計画系論文集、第489、pp.241-247、1996年11月 3）JON..LANG：「建築理論の創造一環境デザインにおける行動科学の役割 一」、今井叻加訳、鹿島出版会、1992
4）CORNELIS VAN DE VEN：「建築の空間」：佐々木宏訳、丸善株式4会 社、昭和 56

5）吉村貞司：「日本の空間楿造」、鹿島出版会、1982

6) OZENFANT \& JEANNERET：「近代絵画」、吉川寏治訳、鹿島出版会、 昭和 43

7) 吉村真司：旧本美の特筫」、鹿島出版会、昭和 42

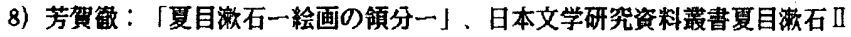

有棈堂、昭和57、pp.248-263

9) 片岡豊：「見るもの」と「見られるもの」と、日本文学研究資料 装書罗目 濑石正、有精堂、昭和60、pp.64-84

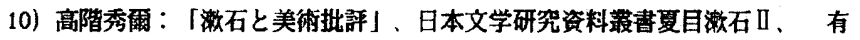
棈堂、昭和57、pp.243-247

11）唡谷行人：「濑石諭集成」、第三文明社、1992

12) Harjorie Boulton：「小説とは何功、今井光规他訳、英宝社、昭和56

13）若山 滋他；「夏目濑石の前期の長編小説の媒台となる建筑空間の「意味 11、日本建筑学会計画系論文集、第478号、pp.131-139，1995年12月

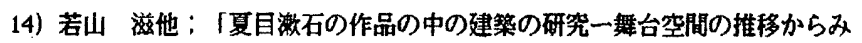
た作品の類型について一1、日本建鹠学会計画系碖文集、第476号、pp.101一 109、1995年10月 